\title{
THE EVOLUTION AND ISSUES ENCOUNTERED IN PROVIDING MEANINGFUL AND USEFUL ONLINE ACCESS TO ORAL HISTORY RECORDINGS
}

Leslie McCartney, University of Alaska Fairbanks, USA

\section{Introduction}

For the past 70 years, or since easy, affordable portable tape recorders could be purchased by almost anyone, there was the push to record the memories of ordinary folk and particularly older people before they passed away and with them, their first-hand knowledge, stories of their life and experiences. If not recorded, when they passed away, these stories and memories would be lost forever. Many of these recordings have become the genre of oral history, that is, the recording of historical information drawn from the narrator's personal knowledge and then the use or interpretation of this recording is used as an academic subject (Thompson, 2000: xi); or as Grele states 'the interviewing of eye-witness participants in the events of the past for the purposes of historical reconstruction (Grele, 1996: 6I). The focus was to record, record and then record more. Individuals recorded narrators, organizations and local history societies undertook oral history projects and more commonly than not, many of these recordings remained in boxes in an organization's offices until they were finally donated to a local archives when the organization realized they could do little with them. While recording and collecting, little thought was given as to how these recordings could be used in future for researchers or anyone interested in the narrator or subject. Thus, we are left with the situation today, how can archivists who now have these recordings in their collections provide meaningful and useful access to these recorded collections (both audio and audiovisual or mixture thereof) for researchers of all kinds and in all locations?

This question is not new. There have been new and creative solutions come to the fore and then disappear as technology has provided more and more tools that provide access to collections. Reflecting back on how access to recordings was achieved prior to the Internet shows us just how far we have come. For example, in Alaska, prior to 1981 there was no oral history or centralized audio collection in the state. Collections instead were scattered about in personal homes and in the offices of many local organizations. After a study revealed these results, William (Bill) Schneider founded the Oral History Program in 198I at the University of Alaska Fairbanks as part of the of the Alaska and Polar Regions Collections in the Elmer E. Rasmuson Library.' The mission of the Oral History program was, and continues to be, to collect, preserve, and provide access to audio and video recordings that provide insight into Alaska's history and the people who have contributed to its heritage. ${ }^{2}$

This however did not really solve the meaningful access to researchers of all kinds in all locations issue. Firstly, researchers had to know that there even was an oral history collection in Alaska. Secondly, they had to know it was at the University, in Fairbanks, and thirdly located in the library on the University campus. Then they physically had to visit the library, navigate through the corridors, descend to the $2^{\text {nd }}$ floor underground and try to navigate the halls to find the office that housed the recordings. Once there, they were rewarded with having to listen to the reel-to-reel or cassette recording in the office while someone, and there were no dedicated oral history staff at this point, searched the multitude of filing cabinets to see if there was a summary, log or transcript. Most likely, the researcher needed to make their own notes of the contents of the recording. The notion of a Gift and Release Agreement or Consent Statement had not been put into practice yet.

\footnotetext{
In email correspondence with the author on December 14,20 6, Schneider recalled that the library had received a grant from the Alaska Historical Commission for him to conduct a survey of existing collections in the state. He does not have, nor can he recall, if a formal report was penned after the study. No published version of this study has been found by the author.

2 Oral History, Elmer E. Rasmuson Library. Last accessed December 13, 20 I6, http://www.library.uaf.edu/oral-history.
} 
That of course was for people who could visit the library. For other researchers in other locations, they would have had to use the library catalog to locate recordings. Early library cataloging was done via the National Union Catalog. ${ }^{3}$ Patrons would then put in a request for a copy to be sent to them from the home library housing the collection. Delivery could take weeks.

Organizing materials held by a library, for example books, maps, audio recordings, needs to be done in a systematic and coherent way so they can efficiently retrieved when requested by a user. The system by which this- is done is known as bibliographic control and bibliographic records of collections are organized into catalogues. (Lazarinis, 20 I5). The Ohio College Library Center or as it became known, OCLC began in 1967 when the Ohio College Library Center wanted to create a cooperative, computerized network for Ohio Libraries and in 197| the first online library occurred. Today, OCLC and its member libraries produce and maintain WorldCat, the largest online public access catalog in the world. ${ }^{4}$ By cataloguing oral history recordings into WorldCat, researchers could find oral history recordings in any library. It was much easier than using the National Union Catalog. With WorldCat, the use of the recordings in a collection started to become more frequent but they still needed to be physically accessed using Inter-Library Loan System.

\section{Project Jukebox is founded ${ }^{5,6}$}

In 1986 Alaska faced a financial crisis, much as it is facing today with shrinking oil revenues leaving the state finances depleted. The Oral History Program at UAF was threatened with elimination.William Schneider, the founder of the Oral History Program, as noted above, acted on a suggestion made by a student who had expressed an interest in investigating the digitization of audio recordings for his master's thesis (Schneider, 20I3: 299-306). He suggested to Schneider that instead of upgrading and copying old recordings, why not digitizing them; this would save time and money. An Apple Library of Tomorrow grant gave them new equipment to create a digitizing station and the digitizing of recordings began. As an added bonus, text and image digitization could also be done with the same equipment.

Schneider then met Steve Ulvi of the National Park Service and he proposed doing a series of interviews in the Yukon-Charley Rivers National Park and Preserve in Alaska. The goal was to collect oral histories of people involved with, or impacted by the creation of Yukon-Charley Rivers National Preserve in east-central Alaska. The narrators include men, women, trappers, miners, educators, historians, archeologists, biologists and government bureaucrats. Some narrators had been associated with the upperYukon for their entire life while others were relative newcomers to the region. Ulvi and Schneider wanted to make these interviews available to a broad audience. This resulted in the first big launch of a 'Jukebox' concept and the National Park Service had the funds to support the endeavor. Thus the first Project Jukebox project was the Yukon-Charley Rivers National Preserve Project Jukebox. ${ }^{7}$

So using HyperCard, the first 'Jukebox' was created in 1988. Project Jukebox was one of the first oral history programs in the United States to provide digital access to oral history recordings. ${ }^{8}$

This was before the Internet so in order to use Project Jukebox, individual cards had to be loaded onto a standalone computer thus the name 'Project Jukebox'. Additionally these stan-

3 These were large printed books that were sent out to libraries and they contained pages and pages of catalog records of books of materials catalogued by the Library of Congress and other American and Canadian libraries.

World Cat. Last accessed November 29, 2016, www.worldcat.org .

Project Jukebox, University of Alaska Fairbanks. Last accessed November 28, 2016, www.jukebox.uaf.edu.

6 For a more in-depth review of the history and philosophy behind Project Jukebox, see William Schneider, "A Jukebox Full of Stories." Oral Tradition 28, no. 2 (2013):299-306.

7 Yukon-Charley Rivers National Preserve Project Jukebox, University of Alaska Fairbanks. Last accessed November 28, 2016 , http://jukebox.uaf.edu/YUCH/index.htm.

8 Technology at Jukebox, University of Alaska Fairbanks. Last accessed December 13, 20 I6, http://jukebox.uaf.edu/site7/tech. 
dalone computers needed to be lugged around from location to location. Schneider recalls them becoming frozen in vehicles in the winter if left overnight. It was a chore to move the equipment from place to place; certainly not easy or convenient but it was the state of the art way to integrate oral history recordings with transcripts or key word summaries, archival photos and maps, making the material accessible to visitors of parks and researchers.

\section{Project Jukebox as access to recordings today}

As the Internet came into being, the Project Jukebox delivery system evolved with the technology. It went from stand-alone Hypercard programs, to web-based HTML programs, to using Testimony Software and then to using Drupal 7.9, 10, "1 Project Jukebox continues to be a grant funded venture with support from the University of Alaska Fairbanks in the form of supporting the IT component of the website and managing the Drupal platform. The technological advances in delivery may have changed but the purpose of Project Jukebox remains the same: to integrate oral history recordings with associated transcripts, photographs, maps, and text while at the same time creating a historical and social context around the subject/topic of the recordings and making this all available to world-wide researchers via internet. Highlights of our current delivery Drupal 7 format of Project Jukebox include: ${ }^{2}$

- An interactive, easy to use and user friendly interface,

- Multiple ways to access the recordings in Project Jukebox - either browse by project, people, interviews or slideshows,

- Listening to the recording in full, jump ahead or back to a particular section, or jump to a particular spot in the transcript to immediately focus on a particular section,

- Access to the entire transcript, or text for the audio appearing under the play bar as a speaker talks,

- More metadata, or information about the actual recording, which can be found under the Digital Assets Information box on an interview page,

- Slideshows associated with an interview, and

- Themes associated with every interview which connect researchers to other recordings that also contain the particular theme terms.

Today, hundreds of the recordings held in the UAF Oral History collection are available online through Project Jukebox and associated with each project are associated transcripts, films, radio programs and photographs and in some projects, research portals and maps.

The following are examples of three projects which include several of the above noted features plus special features to a specific project.

\section{Exxon Valdez oil spill Project Jukebox ${ }^{13}$}

With March 2014 marking the 25th anniversary of the 1989 Exxon Valdez Oil Spill, the then Digital Librarian for the PrinceWilliam Sound Regional Citizens'Advisory Council (PWSRCAC), Alicia Zorzetto, wanted to do something to mark this milestone in Alaska and the nation's his-

9 Testimony Software was created by Turtle Lane Studios Pty Itd. This software delivers synchronized-streamed media. See The Australian Centre for Oral History. Last accessed December 13, 20 I 6, http://www.acoh.com.au/. The Testimony software has been used by a number of organizations, most notably the Cultural Conversations. Last accessed December 13, 2016, http://www.cultconv.com/.

10 For more about the development of Project Jukebox using the Testimony Software, see William Schneider, "A Jukebox Full of Stories." Oral Tradition 28, no. 2 (2013):299-306.

I Drupal is a content and management platform for creating websites. Drupal. Last accessed December |3, 20 |6, https://www.drupal.org/drupal-7.0.

12 Technology at Jukebox, University of Alaska Fairbanks. Last accessed December 13, 20 I 6, http://jukebox.uaf.edu/ site7/tech.

13 Exxon Valdez Oil Spill Project Jukebox, University of Alaska Fairbanks. Last accessed November 28, 20 I6, www.jukebox.uaf.edu/exxonvaldez. 
tory. The focus was on the human aspects of this tragedy, to hear the stories of those involved with, and impacted by, the spill and its aftermath. Partnering with UAF and with funded from PWSRCAC, The Alaska State Library through the Institute of Museum Services and support from Alaska Resources Library and Information Services, the goal was to compile, disseminate and preserve a record of the causes and effects of the oil spill disaster for people around the world to learn from so nothing like this would happen again. Project Jukebox was the perfect platform to achieve these goals.

A total of 35 recordings by 21 people composed of older recordings made by Stan Jones and Sharon Bushell and new recordings made by Zorzetto and Amanda Johnson are featured on the Project Jukebox along with the associated transcripts. ${ }^{14}$ Available from the homepage of the project are also five archival films, ${ }^{15}$, a detailed list of other resources, portions of radio recordings including the first call made by Captain Hazelwood that the ship had run aground and was leaking some oil, to the many hours of public meetings with the oil company, politicians and public where the increasing frustration can be heard escalating day to day. Also available on the project website is a PDF version of Captain Stan Stephens' journal that he kept where he documented his contemporaneous thoughts and feelings about the oil spill as it unfolded. Slideshows made up of some of the narrator's private photos are also featured.

\section{Gates of the Arctic National Park Project Jukebox ${ }^{16}$ | Gates of the Arctic Research Portal ${ }^{17}$}

As in all Project Jukebox projects, the Gates of the Arctic National Park Project Jukebox contains a large number of recordings, transcripts and associated slideshows created from narrators' and archival photographs. The unique feature of this site however is the Research Portal. This portal brings information about a particular village located near the Gates of the Arctic National Park from several databases in several organizations together on one page. If for instance if you want to know what archival films exist about Anaktuvuk Pass, with one click you can find what films there are and where they can be accessed. Nine communities are listed and all contain links to books, images, oral histories, archival films, archival materials, language materials, objects (currently only in PDF but we are hoping in the near future to add the Museum database to our portal), journals, maps, government documents and other collections. Researchers or community members need not look to several databases to find this information, instead the portal collects and updates the information nightly and brings it easily to the user.

\section{Exit Glacier Project Jukebox/Kenai Fjords National Park ${ }^{18}$}

In addition to the online interviews, transcripts, slideshows and links to related materials, this Project jukebox features two interactive maps. ${ }^{19}$ These maps are critical in understanding the interviews as many of the narrators refer to geographic places on the land. These maps highlight the features mentioned in two ways, either by clicking on the name of the narrator in the 'voices' tab or by topic by clicking on the 'Land Use' tab. From the 'voices' tab, users looking

14 The earlier recordings made by Bushell and Jones were used for the basis of their book, The Spill, Personal Stories from the Exxon Valdez Disaster.

I5 Films were made available courtesy of the Alaska Film Archive, Alaska Resources Library \& Information Service and the Seldovia Public Library.

16 Gates of the Arctic National Park Project Jukebox, University of Alaska Fairbanks. Last accessed November 28, 2016, www.jukebox.uaf.edu/gates.

17 Gates of the Arctic Research Portal, University of Alaska Fairbanks. Last accessed November 28, 2016, http://jukebox.uaf.edu/gatesportal7/.

18 Exit Glacier Project Jukebox Kenai Fjords National Park, University of Alaska Fairbanks. Last accessed November 28, 2016, www.jukebox.uaf.edu/exitglacier

19 Exit Glacier Project Jukebox Kenai Fjords National Park, Map of Traditional Uses of the Exit Glacier Area, University of Alaska Fairbanks. Last accessed November 28, 20I6, http://jukebox.uaf.edu/site7/sites/default/files/kenaifjords/voices.html 
for particular features discussed by a particular narrator and easily locate these on the map. For instance the areas in which Ralph and Anne Hatch talk about goat hunting, moose hunting and ptarmigan hunting are easily viewed on the map. Using the 'Land Use' tab, you can easily find trapping or fishing spots discussed in several of the interviews.

\section{URLs to recordings in the Library Catalog ${ }^{20}$}

Project Jukebox is a fantastic delivery method which easily makes recordings and associated archival materials such as film, maps, text and photos available online to researchers but it is completely grant funded and it is not feasible to believe that we can make every recording in our collection available online this way. Increasingly patrons from around the world want access to recordings that are not available through a Project Jukebox.

In 2013 we were able to link audio recordings with associated transcripts or documents directly into the library catalog. Patrons no longer had to wait for materials from the Inter Library Loan System or come into the actual UAF library building to use the materials. Instead, anyone with an internet connection can access for instance a recording made in July 1964 of Bobby Sheldon talking about the first car he brought to Alaska (it was a build it your own kit) in 1904. So here we are, in November 2016,53 years after the recording made and II 3 years after the event, through the online library catalog, we can hear Bobby Sheldon telling us this story (see Figure I).

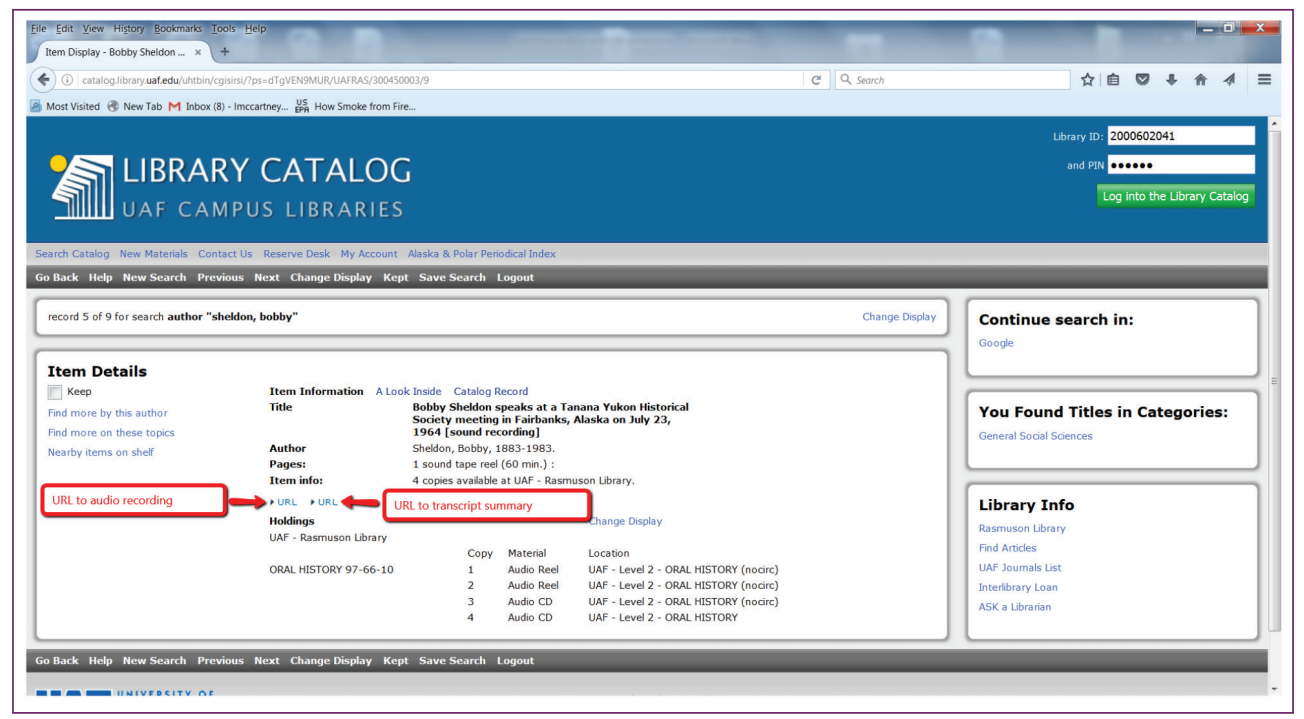

Figure I: UAF Library Catalog record for Bobby Sheldon recording with URL links to recording and transcript summary.

20 Elmer E. Rasmuson Library, University of Alaska Fairbanks. Last accessed November 28, 2016, http://www.library.uaf.edu/. 


\section{Gift and release agreements}

Before making any recordings accessible to researchers or online, we endeavor to secure an up-to-date Gift and Release Agreement that explicitly states "The Library may make this recording electronically accessible via local area networks, the Internet, or other electronic means for access and preservation purposes." An example of the standard UAF Gift and Release Agreement is shown in Figure 2.

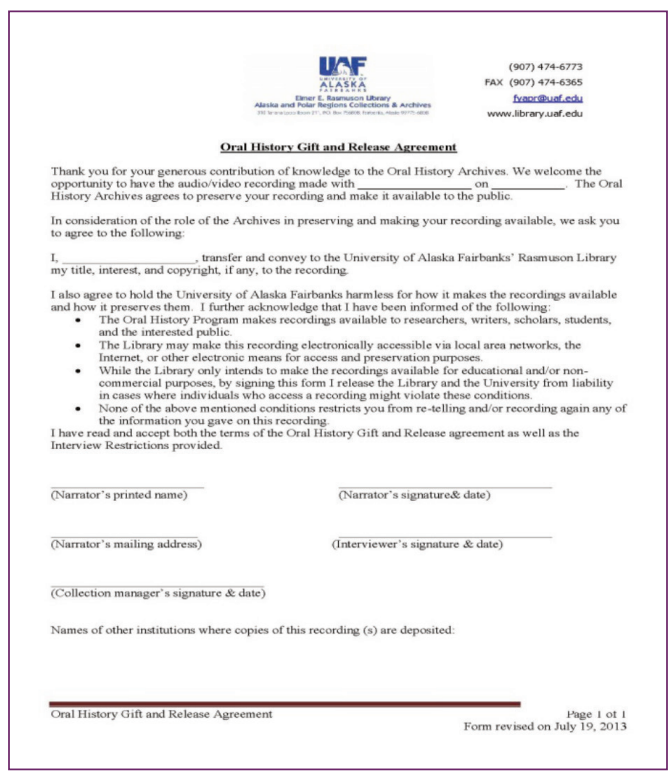

Figure 2: UAF Oral History Gift and Release Agreement.

This can be a very major undertaking given that many of our recordings do not have any sort of Gift and Release Agreement or Consent Statement or if they do, they are very basic and do not include electronic access. This issue came to the fore for the Oral History Collection shortly after the author accepted the position of Curator of Oral History at UAF and learned that a series of $100^{\text {th }}$ year University anniversaries would be happening over the next couple of years. The author realized that there were hundreds of recordings in the UAF Oral History collection that the university had made over the years featuring past university Presidents and Chancellors, distinguished scholars, the opening of various campus buildings and other historic university events. These recordings had been created by the university for the university yet there was no paperwork associated with most of these recordings and therefore legally and ethically they could not be used.

Realizing that the UAF Oral History Collection could make a significant contribution to and celebration events, the author contacted the UAF legal team. Their solution was to create a License Agreement which states:

"The University of Alaska and the University of Alaska Fairbanks hereby grant a perpetual, non-exclusive, royalty free, paid-up, worldwide license to the Rasmuson Library for use of the University of Alaska oral history audio recordings created between January I, 1940 and December 3I, I 999 that are currently held by the Rasmuson Library in its oral history collection. The Rasmuson Library is expressly authorized to make these recordings available through its Oral History Program to researchers, writers, scholars, students, and the interested public for access and preservation purposes through any means available, including but not limited to electronic mean and the internet. The recordings shall be available only for educational and/or non-commercial purposes". A copy of our standard License Agreement is illustrated in Figure 3. 


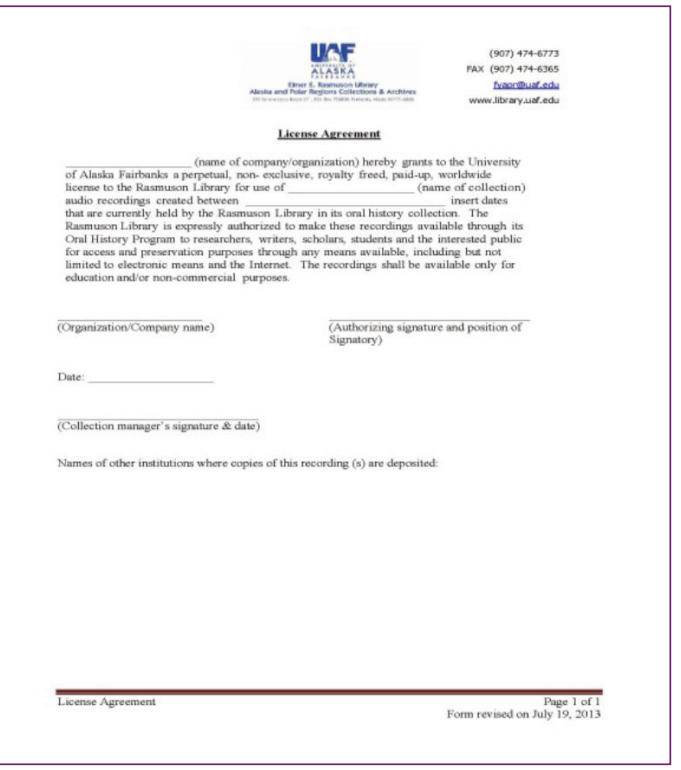

Figure 3: UAF License Agreement.

This effectively freed up all of the UAF recordings to now be used for the anniversary celebrations and any other research into the history of the University. ${ }^{21}$

The author has since implemented this solution with many of our other collections that have been donated to us by organizations over the years. For example, recordings collected in the 1960-80s by the Pioneers of Alaska and the Tanana Yukon Historical Society. Most of the people interviewed have long passed away; the organizations donated the recordings to us long before Gift and Release Agreements were the norm. On many of the recordings they say that the recording will be archived at UAF for future generations to learn from. The author has also asked organizations such as school districts that donated recordings to us to sign similar agreements along with Arts Councils and other local history groups. To date, not one organization has declined. These recordings were created and archived with UAF to be used by researchers and the general public. By signing these UAF License Agreements, it allows us to freely use thousands of recordings that were previously not available to the public as there was no permission to do so. As shown in figure 3 and as noted above, these License Agreements give the Rasmuson Library authority to make these recordings available through the Oral History Program to researchers, writers, scholars, students and the interested public and it also allows us to make them also electronically available through internet. It explicitly states that the recordings are for education and/or non-commercial purposes only. The author realizes that this is not the only solution for making large collections available; Creative Commons is also an option. ${ }^{22}$ The UAF legal department directed us toward using the UAF License Agreement they had prepared and as shown above in Figure 3.

21 In personal correspondence to the author on April 2, 20 I3, UAF Legal Council decided on using a License Agreement over a transfer or assignment as the university already owned the rights to the recordings themselves.

22 Creative Commons. Last accessed December 14, 20I5, https://creativecommons.org/. 
The largest achievement using this method to date came in 2014 when we discovered we had 163 recordings related to the Exxon Valdez oil spill that occurred in Prince William Sound, Alaska in 1989. As noted above, from the first recording by Captain Hazelwood reporting that the ship had run aground and was leaking oil to the first radio news broadcasts, to the public meetings that continued for months and months thereafter. The recordings contain public radio news coverage of the spill from March 24 to December 3I, 1989.

We discovered that the collection had been given to us by either a radio station and/or the Alaska State Archives in 1990. Copies were also given to five other institutions/repositories and four radio stations all within Alaska. The letter accompanying the recordings in 1990 clearly set out that the original intent was not to circulate the recordings outside the library and although not stated, this was for reasons of the several legal suits filed after the spill. The author contacted each of the five institutions and four radio stations explaining the Exxon Valdez Oil Spill Project Jukebox and her wish to add a selection of the various radio broadcasts from our collection to the online Jukebox. This would give users a real sense of the growing frustration of the citizens affected by the spill as the days went on and the response of the oil companies at the time. Time had now passed; the court cases had been settled. Every radio station and repository agreed that these recordings should be made public. 2014 was after all the year of the $25^{\text {th }}$ anniversary of what at the time was the worst oil spill in the world and we were creating a Project Jukebox with several recordings and wanted to include Hazelwood's first call and various days of meetings. Every organization and radio station agreed to sign a License Agreement. Today you can listen to portions of these recordings online. ${ }^{23}$ All of the recordings are now open to the public and will be made available to researchers on request.

But what of recordings that were not made by or donated by organizations that we wanted to include in a Project Jukebox or link via a URL to the recording in the Library Catalog? Retired United States Judge and oral historian John A. Neuenschwander refers to these types of recordings as 'the orphan interview problem' which he defines as 'work that contains enough originality to be copyrightable but whose owner or creator cannot be found (Neuenschwander, 20 I4: 83). Such a work could be a film, musical recording or photograph. It could also be an oral history interview for which there is no signed release. Many of the recordings in the category contain invaluable information and to make them not available because they might have been recorded in the 1940s and 1950s and it is unlikely that the people are still alive seems a poor practice for making these primarily resources available to researchers. After attending a workshop by Neuenschwander entitled Oral History and the Law at the Oral History Association Annual Meeting in Cleveland, Ohio in October 2012, the author decided we would implement his due diligence and fair use doctrine to our collection. Our guidelines became as follows:

- An orphan work is identified in our collection, that is, a recording that has either no Gift and Release agreement was ever signed or if on was, it does not meet today's standards of allowing us to make it electronically available

- On a purposely set up spreadsheet we log in the recording number and metadata (interviewer/interviewee name, date, collection, series etc.); all of the next steps detailed are logged in with the date of the search

- We do an internet and database search for an obituary looking for any clues to next of kin and their location

- If any clues are found, follow up steps are next (search for telephone numbers or addresses and write or call the next-of-kin for example)

- Alaska may be geographically big but it population small; depending on the interview details, contact someone in the village that may know of the narrator or next-of-kin

23 Exxon Valdez Oil Spill Radio Recordings, University of Alaska Fairbanks. Last accessed November 28, 20 I6, http://jukebox.uaf.edu/site7/exxon-valdez-oil-spill-radio-recordings. 
- Search to see if there any further archival collections in our institution and if so, search files for contact or next-of-kin details

- If any of these searches are successful, ask for an updated Gift and Release Agreement to be signed, give copies of the recording/transcript to the family and release to public

- After a minimum of three solid efforts to find any information and the narrator and next-of-kin, and if this search is unsuccessful, make the recording and associated transcript (if there is one) available yet note on the series catalog record that a new Release is needed

We have been very successful with this practice. The following is just one example:

In October 2014 we were contacted by a researcher who was writing a memoir of her uncle who had been a practicing doctor in Alaska many years ago. She found on WorldCat reference to a recording in our collection by a Dr. Arthur Wilson who had been interviewed in 1982. Although this was not her uncle, Dr.Wilson had practiced medicine in Alaska about the same time as her uncle and she wanted to look at the transcript for some historical context for her writing. The author checked our Gift and Release Agreements and they were indeed the old ones where electronic distribution of the material had not been consented to. UAF Oral History staff knew that the interviewer had passed away. This was our first test of Neuenschwander's due diligence and fair use doctrine. A quick Internet search revealed that Dr.Wilson was no longer practicing but his son was also a physician in Alaska. The author contacted the information on the website about his address and telephone number. The phone had been disconnected, the practice closed. The author contacted the Director of the hospital in the town where Dr.Wilson had practiced along with a few other doctor offices in the same town. Everyone remembered Dr.Wilson and his son but they had both long retired, moved away and no one knew their whereabouts or if they were indeed still alive. Other internet searches did not reveal Dr.Wilson or his son. This amounted to five serious attempts to locate Dr.Wilson. We released the transcript electronically to the patron and put a URL to the .mp3 into the library catalog record so she could listen to the recording. In April $2015 \mathrm{Dr}$. Wilson's great-granddaughter found the recording through WorldCat when conducting family genealogy research. She contacted us, thrilled to find this recording, her family never knew of its existence and she thanked us, on behalf of her family, and expressed how much find this recording meant to her family. Her father was still alive and was more than happy to sign a new Gift and Release Agreement. They were equally pleased to have learned the recording had assisted a researcher.

We have implemented this procedure many times and in many cases, family members have found the recordings WorldCat when conducting family research searches and are only too pleased to sign a new Gift and Release Agreement. 


\section{Conclusion}

Using the University of Alaska Fairbanks Project Jukebox and online cataloging as an example, we have seen how technological delivery audio and audiovisual recordings, along with associated transcripts maps and related texts has evolved. Making recordings available online however requires a due diligence and fair use attempt to obtain legal consent from the narrator or their descendants to do so. Alternatively, License Agreements may be a solution for large collections recorded by institutions as in the case of the UAF recordings. In an email from the UAF Legal Counsel to the author dated March 29, 20I3, it was noted that one must keep in mind however that other copyright issues could arise, for example speakers may have copyright interest in their recorded speeches but an improvised speech is not a fixed work and there is no copyright attached. Given that there may be some risk that works put online under these agreements might be subject to copyright, the risk is fairly minimal and dealt with if an objection arises at a later date. To date this has not been the experience of UAF. Decisions to put materials online with proper permissions has led the UAF Oral History Program today to a way to provide meaningful and useful access to these recorded collections for researchers in any location worldwide as long as they can be connected to the internet. As technological delivery systems change in future, we can only imagine what meaningful delivery systems to our collections will look like in future.

\section{Acknowledgements}

The author would like to thank the following people who assisted with providing or clarifying information and background context for conference presentations of which this paper is based on: John Byrne, Karen Brewster, Joann Henszey, Robyn Russell and William Schneider.

\section{References}

Bushell, Sharon and Stan Jones. (2009). The Spill. Personal Stories from the Exxon Valdez Disaster. Alaska: Epicenter Press.

Grele, Ron. (1996).'Directions for oral history in the United States, in Oral History: An Interdisciplinary Anthology, $2^{\text {nd }}$ edition', eds. D.K. Dunaway and W. K. Baum. (Walnut Creek, CA:AltaMira Press, 1996), 63.

Lazarinis, Fotis. (20I5). Cataloguing and Classification. An introduction to AACR2, RDA, DDC, LCC, LCSH and MARC 2 I Standards, I ${ }^{\text {st }}$ edition. Amsterdam: Elsevier, I, 2.

Neuenschwander, John A. (20I4). A Guide to Oral History and the Law, $2^{\text {nd }}$ edition. Oxford: Oxford University Press.

Perks, Robert and Alistair Thomson. (2016). The Oral History Reader, $3^{\text {rd }}$ edition. New York: Routledge.

Schneider,William. (20I3). “A Jukebox Full of Stories.” Oral Tradition 28, no.2:299-306.

Thompson, Paul. (2000). The Voice of the Past. Oral History, $3^{\text {rd }}$ edition. Oxford: Oxford University Press. 


\section{Websites}

Creative Commons. Accessed: December 14, 2015, https://creativecommons.org/

Cultural Conversations. Accessed: December 13, 2016, http://www.cultconv.com/.

Elmer E. Rasmuson Library, University of Alaska Fairbanks. Accessed: November 28, 2016, http://www.library.uaf.edu/.

Exit Glacier Project Jukebox Kenai Fjords National Park, University of Alaska Fairbanks. Accessed: November 28, 2016 , www.jukebox.uaf.edu/exitglacier

Exit Glacier Project Jukebox Kenai Fjords National Park, Map of Traditional Uses of the Exit Glacier Area, University of Alaska Fairbanks. Accessed: November 28, 2016, http://jukebox.uaf.edu/site7/sites/default/files/kenaifjords/voices.html

Exxon Valdez Oil Spill Radio Recordings, University of Alaska Fairbanks. Accessed: November 28, 2016 , http://jukebox.uaf.edu/site7/exxon-valdez-oil-spill-radio-recordings.

Exxon Valdez Oil Spill Project Jukebox, University of Alaska Fairbanks. Accessed: November 28, 2016, www.jukebox.uaf.edu/exxonvaldez.

Gates of the Arctic National Park Project Jukebox, University of Alaska Fairbanks. Accessed: November 28, 2016, www.jukebox.uaf.edu/gates.

Gates of the Arctic Research Portal, University of Alaska Fairbanks. Accessed: November 28, 2016, http://jukebox.uaf.edu/gatesportal7/.

Oral History, Elmer E. Rasmuson Library. Accessed: December 13, 2016, http://www.library.uaf.edu/oral-history.

Project Jukebox, University of Alaska Fairbanks. Accessed: November 28, 2016, www.jukebox.uaf.edu.

Technology at Jukebox, University of Alaska Fairbanks. Accessed: December 13, 2016, http://jukebox.uaf.edu/site7/tech.

The Australian Centre for Oral History. Accessed: December 13, 2016, http://www.acoh.com.au/.

Yukon-Charley Rivers National Preserve Project Jukebox, University of Alaska Fairbanks. Accessed: November 28, 2016, http://jukebox.uaf.edu/YUCH/index.htm.

WordCat. Accessed: November 28, 2016, www.worldcat.org. 